\title{
Investor Reaction to Mandatory Offers on the Warsaw Stock Exchange
}

\author{
Szymon Okoń
}

ABSTRACT

The following paper aims to assess investor reaction to mandatory offers on the Warsaw Stock Exchange, which is important because knowledge about these reactions can be used to make better investment decisions. This paper highlights the importance of procedure in making a mandatory offer and its grounds in the Polish legal system. Additionally, it presents empirical research on the reactions of investors to mandatory offers on the Warsaw Stock Exchange. It has been provided that mandatory offers have a significant impact on the price of a company's shares listed on the Warsaw Stock Exchange. Knowledge about the reactions of investors to a mandatory offer may be used when selecting securities for an investment portfolio. The findings may provide guidance in deciding whether to begin or end investment in the company, both for individual and institutional investors. The event study methodology approach used in the paper is regarded as valuable and can be the basis for further research in other areas of the capital market research, especially in the context of information efficiency.

KEY WORDS: $\quad$ mandatory offer, event study, investors' reactions

JEL Classification: $\quad$ G14

${ }^{1}$ Poznań University of Economics, Poland

\section{Introduction}

A mandatory offer for shares is closely linked to a change in the control of a company listed on the public market. The conditions for carrying out such transactions vary significantly, depending on the characteristics of the particular capital market. The first factor considered by this paper is the legislation that shapes the market because it has a direct impact on mandatory offers by delineating exactly how to proceed with certain actions. Second, this paper considers the model of the capital market. It determines the general activity on the mandatory offers market.

-

Corespondence concerning to this article should be addressed to: szymon.okon@ue.poznan.pl

\section{Mandatory offers on capital markets}

When analysing the issue of mandatory offers, problems of information efficiency in capital markets should be emphasised. Any discussion of that subject should refer to the hypothesis of capital market efficiency (efficient market hypothesis) (Roberts, 1967; Fama, 1970). The efficient market hypothesis assumes that all available information about securities, including public announcement on mandatory offers, is reflected in the prices of shares at any time. Deviations from the informational efficiency are referred to as "capital market anomalies". They usually relate to the time of the transaction, delayed reactions of investors to information, overreactions of market participants in response to incoming information and momentum strategy (Szyszka, 2003). According to the classic definition of capital market efficiency, prices immediately 

The event study methodology is commonly used to assess investors' reactions to many different events: announcements about splits of shares (Fama, Fischer, Jensen \& Roll, 1969), changes in the dividend policy (Aharony \& Swary, 1980; Amihud \& Murgia, 1997; Charest, 1978; Divecha \& Morse, 1983; Kwan, 1981; Pattel \& Wolfson, 1984), issuance of new shares (Asquith \& Mullins, 1986; Kolodny \& Suhler, 1985; Masulis \& Korwar, 1986), repurchase of shares (Dann, 1981; Szyszka \& Zaremba, 2011; Vermaelen, 1981) as well as recommendations of analysts (Barber \& Loeffler, 1993; Beneish, 1991; Davis \& Canes, 1978; Liu, Smith \& Syed, 1990). The general aim of event study analysis is to determine the impact of the particular event on the value or volume traded of shares of a particular company listed on the stock exchange. To carry out the research, the date and circumstances of the event occurrence should be identified.

It should be noted that the publication of new information relating to a specific company is usually understood as the event in question. The company may cause the event directly (coming from the company, related to the company's activities) or indirectly (the source of information may be another entity).

When conducting event study analysis, it is crucial to determine the parameters of the event window and the estimation window. The event window is defined as a period of time (measured in days, weeks, months or even years) in which changes in price or the volume of shares traded for the selected companies are to be analysed. The estimation window is the period in which the parameters of appropriate models are estimated. Next, these parameters are used to generate the expected returns of shares in the event window. The estimation window is usually immediately prior to the event window.

The next step of the analysis is to determine the relation between the returns of a company's shares and the returns of an index, which represents a market portfolio. The calculation of abnormal returns can be made in different ways, e.g., using the market model, the capital asset pricing model, the mean model or the index model. The most common model to use is the market model. In this paper, abnormal returns are calculated in accordance with the following formula:

$$
r_{A R}=r_{i t}-\left(\alpha_{i}+\beta_{i} r_{m t}\right)
$$

where:

$r_{A R}$ - abnormal rate of return,

$r_{i t}$ - rate of return on the particular company's shares, $\alpha_{i}$ and $\beta_{i}$ - parameters estimated in estimation window using the classical least squares method,

$r_{m t}$ - rate of return on market portfolio.

After calculating the abnormal returns, the cumulative abnormal returns in the event window for each company from the sample are computed. Subsequently, the mean abnormal return for each trading day in the event window is computed, which gives the average cumulative abnormal returns.

Because a statistical inference is verified at a later stage, the application of appropriate statistical tests is required. One method of statistical significance verification is a traditional Student's t-test. However, sometimes this statistic is not sufficient and cannot be used in general. Therefore, nonparametric tests must be applied, e.g., rank tests or simulation methods, especially bootstrap methods (Efron, 1979; MacKinnon, 2006).

\section{Empirical study of the investors' reactions to mandatory offers}

The research conducted in this paper is based on the full history of companies listed on the Warsaw Stock Exchange in the period from 14 February2007, to 8 January 2010. The closing prices of a particular company's shares during the trading days have been used. The public announcements of the companies listed on the Warsaw Stock Exchange were the source of information about mandatory offers in the event study. These data were obtained from the site www.gpwinfostrefa.pl.

The period of event study analysis (mandatory offers for shares) started in 2007 when the global financial markets moved into a downturn phase. The peak occurred on July 6, 2007, when the WIG index reached its highest historical value. This moment has become a criterion of eligibility for the admittance of further mandatory offers to the study. The first mandatory offer was on August 23, 2007. The end of the study period occurred when the first stage of economic recovery had finished. According to this criterion, the last event was the mandatory offer on December 22, 
2009. The study includes in its time scope the slump and the first phase of recovery of the financial markets. Additionally, to test the overall reaction of investors to mandatory offers during the study period, two sub-periods have been distinguished during which the same event was analysed separately. This division provided the basis for an interesting comparison and final conclusions. The criterion for the division was the change of the financial market in Poland from the bear market phase to the recovery phase, which occurred on February 17, 2009, when the WIG index reached its lowest value during the study period. The performance of the WIG index during the period 2007 to 2009 is presented below.

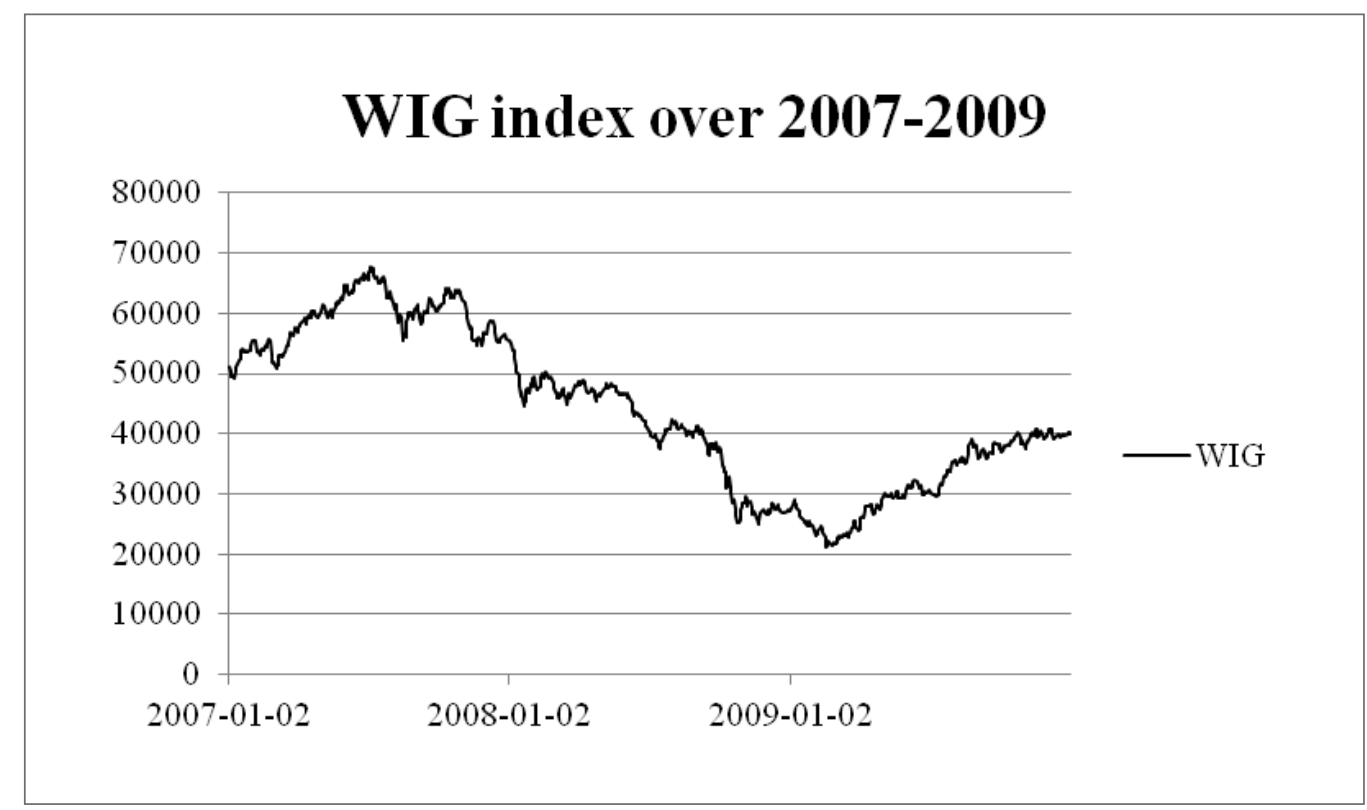

Figure 1. WIG index over 2007-2009

The study was carried out on the basis of the calculation of abnormal returns. This calculation indicates additional returns compared to returns based on historical trends, using estimated parameters. The reaction of investors to an announcement of mandatory offers is reflected in this difference.

The returns of shares on the market depend on a general factor that characterises the stock market. The effect of this factor is reflected in changes in the value of a market index. The market indicator is the rates of return on a market portfolio, in this case the WIG index. The calculation of abnormal returns compared to the market model were generated as follows:

$r_{i t}=\alpha_{i}+\beta_{i} r_{m t}+e_{i t}$,

where:

$r_{\text {it }}$ - daily rate of return on shares of $\mathrm{X}$ at time $\mathrm{t}$, $r_{m t}$ - daily rate of return from WIG index in period $\mathrm{t}$, $\mathrm{e}_{i t}$ - random component,

$\alpha_{i}$ - parameter alpha estimated on the basis of the market model,

$\beta_{i}$ - beta parameter estimated on the basis of the market model.

For the purposes of estimating parameters $\alpha_{i}$ and $\beta$, the classical least squares method was used. These estimates were based on the observation of the relationship between the rates of return of the particular company and the rates of return from the market portfolio in the estimation window.

Note that the equation for abnormal returns (derived from a market model) can be divided into two parts. The rate of return $r_{\text {it }}$ is linearly dependent on the returns on the market portfolio (systematic compo- 
nent) and is independent of the market element (nonsystematic component). Therefore, it can be assumed that the effect of the event will be fully reflected in the non-systematic component, according to the following equation:

$e_{i t}=r_{A \mathrm{R}} e_{i t}=r_{A R}$,

where:

$\mathrm{e}_{\mathrm{it}}$ - random component,

$r_{A R}$ - daily abnormal return on shares of X.

The random component occurring in the model can be interpreted as the effect of all factors unrelated to the market index, on which the rate of return of shares also depends.

After calculating the abnormal returns, the cumulative abnormal returns for each company within the sample (in the period between a and b) are computed (CAR):

$$
C A R_{a-b}=\sum_{a=b}^{a} r_{A R}
$$

where:

CAR ${ }_{a-b}$ - cumulative abnormal return in the period a to $b$,

$r_{A R}$ - daily abnormal return on shares of X.

The next step calculates the average cumulative abnormal return (ACAR) according to the following formula:

$$
A C A R_{a-b}=\frac{\sum_{i=1}^{n} C A R_{a-b}}{n}
$$

where:

$A C A R_{a-b}$ - average cumulative abnormal return over $\mathrm{a}$ and $\mathrm{b}$,

$C A R_{a-b}$ - cumulative abnormal return in the period between a and $b$,

$n$ - number of all companies analysed in the sample.

Following the above calculations, the average cumulative abnormal returns for each trading day within the event window were provided.

The statistical significance verification of the average abnormal returns was conducted using a modified Student's t-test and a nonparametric Corrado rank test (Cor- rado, 1989; Corrado, 1992). The null hypothesis assumed that the average abnormal return in the session $t$ in the event window is statistically insignificantly different from zero. In the case of the parametric test indicated above, if the average abnormal returns have independent normal distributions, the Student's t-distribution employs N-1 degrees of freedom. However, in the case of the Corrado rank test, assuming the truth of the null hypothesis implies an asymptotically normal distribution.

This study analysed 54 public mandatory offers for shares on the Warsaw Stock Exchange occurring in the period from 6 July 2007, to 22 December 2009. The period was divided into two sub-periods, thereby making it possible to observe the reaction of investors separately during the bear market and recovery phases.

After making all calculations in accordance with the methodology outlined above, a graph was prepared to assess the reaction of investors to the mandatory offers for shares on the Warsaw Stock Exchange. The profile of the average cumulative abnormal returns allowed for conclusions to be drawn about the behaviour of investors.

In terms of statistical significance verification, the modified Student's t-test remains significant at the 1 per cent level in sessions $\mathrm{t}=-3, \mathrm{t}=0$ and $\mathrm{t}=1$, while the Corrado rank test confirms the statistical significance and indicates the significance at the 5 per cent level in sessions $\mathrm{t}=-3, \mathrm{t}=-2, \mathrm{t}=0$ and $\mathrm{t}=1$. Statistics are insignificant in the remaining sessions within the scope of the event window.

The profile of the average cumulative abnormal returns for the entire period is as follows: this particular rate of return rises from $t=-5$ to $t=1$, which is followed by a reversal and decline. Similar phenomena regarding the average cumulative abnormal returns are observed for mature markets (Asquith, 1983; Dodd \& Ruback, 1977; Jensen \& Ruback, 1983; Keown \& Pinkerton, 1981). U.S. market research has shown that in the period preceding the announcement, the average cumulative abnormal returns are more or less at a constant positive level, experiencing a fairly significant increase in the days immediately preceding the announcement of the mandatory offer (Dodd \& Ruback, 1977; Lewandowski, 2000). Such movement in the average cumulative abnormal returns can be interpreted as a reflection of event anticipation by the market participants, as well as insider trading. 
Investors' reaction to mandatory offers on the Warsaw Stock Exchange over 2007-2009

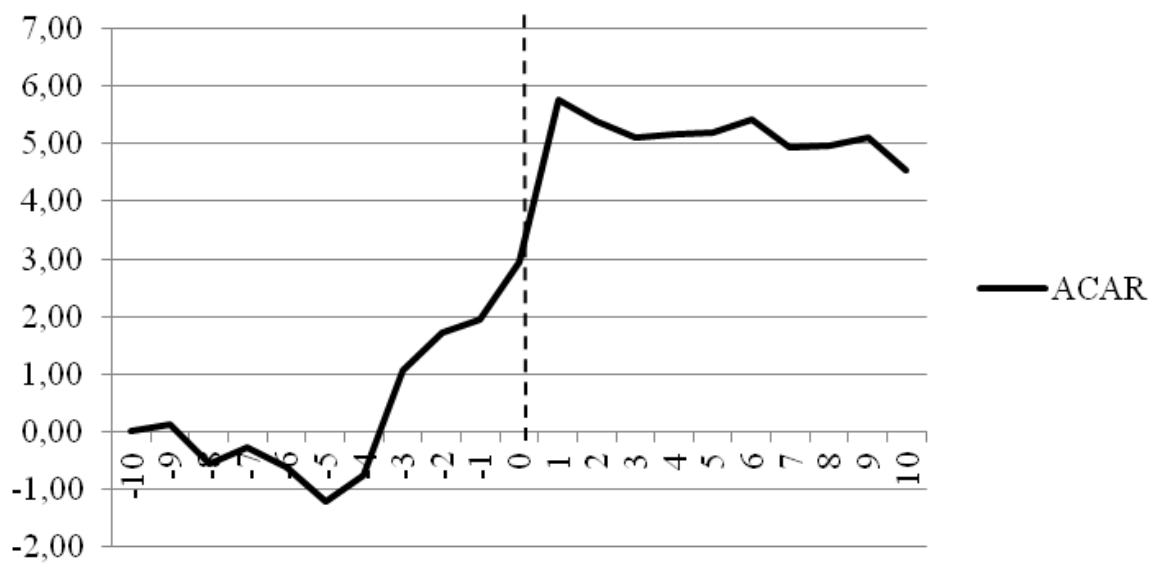

Figure 2. Average cumulative abnormal return for mandatory offers for shares on the WSE in 2007-2009.

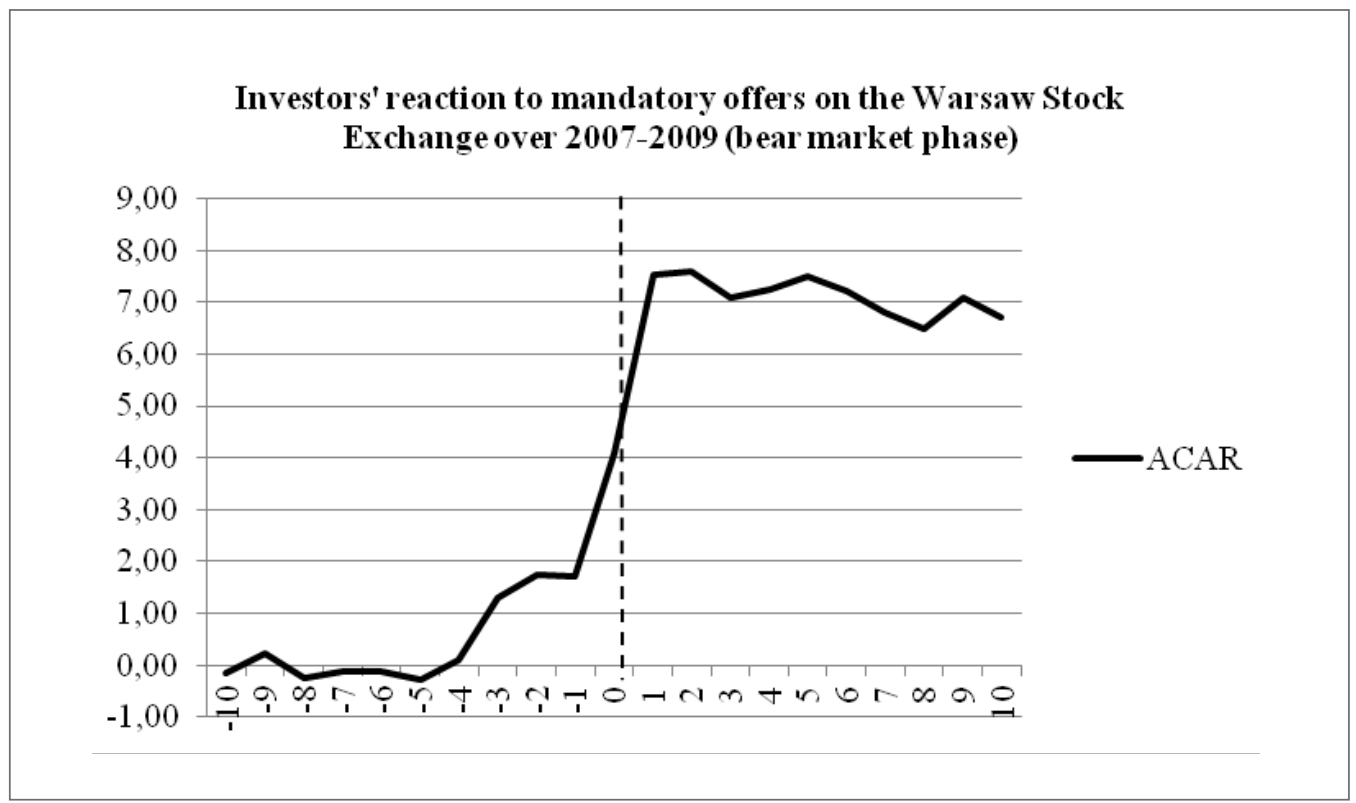

Figure 3. Average cumulative abnormal return for mandatory offers on the WSE in the bear market phase. 


\section{Investors' reaction to mandatory offers on the Warsaw Stock Exchange over 2007-2009 (recovery phase)}

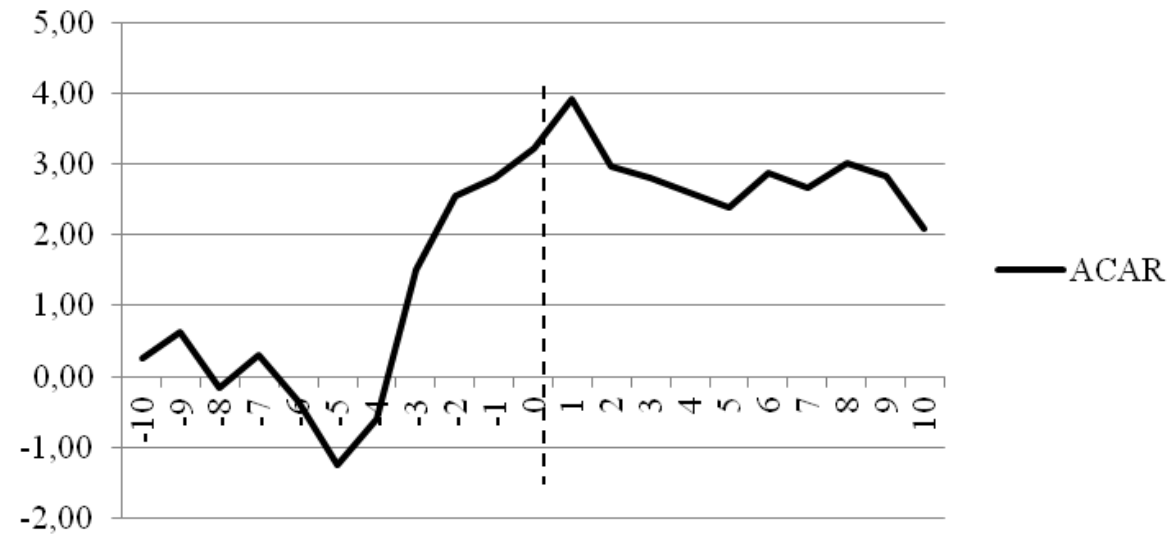

Figure 4. Average cumulative abnormal returns for mandatory offers for shares on the WSE in the recovery phase

As indicated above, the analysed period was divided into two sub-periods. During the first period, from July 2007 to January 2009, 31 mandatory offers were observed, while during the second period, from February 2009 to December 2009, 23 mandatory offers were observed.

For each sub-period, the relevant graphs were drawn based on available data. The graphs were prepared to assess the reaction of investors to the mandatory offers for shares on the Warsaw Stock Exchange. Based on the profile of the average cumulative abnormal returns, conclusions have been drawn.

During the bear market phase, the Student's t-test confirms the statistical significance at the 1 per cent level in sessions $\mathrm{t}=0$ and $\mathrm{t}=1$, while the Corrado rank test confirms the statistical significance at the 5 per cent level over the same trading days. In the remaining sessions in the event window, the statistics are insignificant.

During the recovery phase, the modified Student's $\mathrm{t}$-test is significant at the 1 per cent level only in session $t=-3$. The remaining sessions in the event window are statistically insignificant. The Corrado rank test shows no statistical significance.

Separate analysis of investors' reactions for each of the sub-periods is required. First, it should be noted that during the bear market phase, relatively higher average cumulative abnormal returns compared to those obtained in the recovery phase are observed. In the bear market phase, the highest abnormal return value was 7.61 per cent in session $t=2$, while in the recovery phase, the highest value was 3.93 per cent and occurred during session $t=1$. In both cases, there is an increase in the average cumulative abnormal return from session $t=-5$ and a slight drop off after the session during which the highest average cumulative abnormal return was observed. This phenomenon is similar to the result of research conducted over the whole period.

Comparing changes in the average cumulative abnormal returns over the sessions from $t=-5$ to $t=2$ reveals an interesting result. In the study involving mandatory offers during the bear market phase, there is a slight increase in the value of the average cumulative abnormal returns in sessions from $t=-5$ to $t=$ -1 . Immediately following that period, there is a sharp increase in the average cumulative abnormal returns from a level near 2 per cent up to a value of 7.61 per cent in session $t=2$. This is markedly different from the recovery phase. During that phase, the dynamic growth observed in sessions from $t=-5$ to $t=-2$ and subsequently until session $\mathrm{t}=1$ remains moderate. 

Charest, G. (1978). Dividend Information, Stock Returns, and Market Efficiency II. Journal of Financial Economics, 6(2/3), 297-330.

Corrado, C.J. (1989). A non parametric test for abnormal security price performance in event studies. Journal of Financial Economics, 23(2), 385-395.

Corrado, C.J., \& Zivney, T.L. (1992). The specification and power of the sign test in event study hypothesis tests using daily stock returns. Journal of Financial and Quantitative Analysis, 27(3), 465-478.

Craig, M. (1997). Event studies in economics and finance. Journal of Economic Literature, 35(1), 1339.

Dann, L. (1981). Common Stock Repurchases: An Analysis of Returns to Bondholders and Stockholders. Journal of Financial Economics, 9(2), 115-138.

Davis, P. L., \& Canes, M. (1978). Stock Prices and the Publication of Second-Hand Information. Journal of Business, 51(1), 43-56.

Dimson, E., \& Marsh, P. (1986). Event study methodologies and the size effect. Journal of Financial Economics, 17(1), 113-142.

Divecha, A., \& Morse, D. (1983). Market Responses to Dividend Increases and Changes in Payout Ratios. Journal of Financial and Quantitative Analysis, 18(2), 163-173.

16. Dodd, P., \& Ruback, R. (1977). Tender Offers and Stockholder Returns. Journal of Financial Economics, 5(3), 351-373.

Efron, B. (1979). Bootstrap Methods: Another Look at the Jackknife. Annals of Statistics, 7(1), 1-26.

Fama, E.F., Fischer, L., Jensen, M., \& Roll, R. (1969). The Adjustment of Stock Prices to New Information. International Economic Review, 10(1), 1-21.

Fama, E.F. (1970). Efficient Capital Markets: A Review of Theory and Empirical Work. The Journal of Finance, 25(2), 383-417.

Jensen, M., \& Ruback, R. (1983). The Market for Corporate Control. Journal of Financial Economics, 11(1-4), 5-50.

Keown, A., \& Pinkerton, J. (1981). Merger Announcements and Insider Trading Activity: An Empirical Investigation. Journal of Finance, 36(4), 855-869.

Kolodny, R., \& Suhler, D. (1985). Changes in Capital Structure, New Equity Issues, and Scale Effects. Journal of Financial Research, 3(2), 127-136.
Kwan, C. (1981). Efficient Market Tests of the Information Content of Dividend Announcements: Critique and Extension. Journal of Financial and Quantitative Analysis, 16(2), 193-206.

Lewandowski, M. (2000). Fuzje i przejęcia w Polsce na tle tendencji światowych [Mergers and acquisitions in Poland against the global trend]. Warszawa: WIG-Press,

Liu, P., Smith S., \& Syed, A. (1990). Stock Market Reactions to The Wall Street Journal's Securities Recommendations. Journal of Financial and Quantitative Analysis, 25(3), 399-410.

MacKinnon, J.G. (2006). Bootstrap Methods in Econometrics. The Economic Record, 82: S2-S18.

Masulis, R., \& Korwar, A. (1986). Seasoned Equity Offerings: An Empirical Investigation. Journal of Financial Economics, 15(1-2), 91-118.

McDonald, B. (1987). Event Studies and Systems Methods: Some Additional Evidence. Journal of Financial and Quantitative Analysis, 22(4), 495-504.

Pattel, J., \& Wolfson, M. (1984). The Intraday Speed of Adjustment of Stock Prices to Earnings and Dividend Anniuncements. Journal of Financial Economics, 13(2), 223-252.

Roberts, H. (1967). Statistical Versus Clinical Prediction of the Stock Market, Center for Research in Security Prices, University of Chicago.

Sallinger, M. (1992). Standard errors in event studies. Journal of Financial and Quantitative Analysis, 27(1), 39-53.

Szyszka, A. (2003). Efektywność Giełdy Papierów Wartościowych $w$ Warszawie na tle rynków dojrzałych [Efficiency of the Stock Exchange in Warsaw against the mature markets], Poznań:. Wydawnictwo Akademii Ekonomicznej w Poznaniu,.

Szyszka, A., \& Zaremba, A. (2011). The Buyback Anomaly on the Polish Capital Market. Finanse Rynki i Ubezpieczenia, 38, 481-494.

Vermaelen, T. (1981). Common Stock Repurchases and Market Signaling. Journal of Financial Economics, 9(2), 139-183. 
